\title{
SUSTAINABILITY GOALS AND THEIR IMPLEMENTATION IN SHORT SUPPLY CHAINS IN HUNGARY
}

\author{
Gabor Koncz, Zoltan Bujdoso, Antonia Szucs \\ Hungarian University of Agriculture and Life Sciences, Hungary \\ koncz.gabor@uni-mate.hu, bujdoso.zoltan@uni-mate.hu, szucs.antonia@uni-mate.hu
}

\begin{abstract}
Utilization of local resources and positioning of local actors is a priority area of rural development. In recent years, the sale of local products and the development of related short supply chains (SSCs) have also been a popular topic in support policy and rural development research. Support for the shortening of supply chains is also justified by assuming their positive effects on the majority society from an environmental, economic and social point of view. New types of SSC channels can be a very diverse regional pattern of how local food producers are able to compete with globalized food chains. This also largely depends on the compromises that producers and consumers are able to make in order to maintain local food systems, which mostly requires the cooperation (adaptation) of the actors. In the framework of our research, we sought the answer to the extent to which the sustainability aspects that can be considered among their advantageous properties can prevail in model SSCs. Therefore, we interviewed 20 producers about which forms of sales in short supply chains are preferred and to what extent the elements of sustainable development prevail in their activities. While we also find some really innovative solutions for organizing local food systems in Hungary, it is also a typical experience that some forms of support are not favored by producers, or that bottom-up consumer initiatives die in the initial stages of cooperation. The interests of economic growth or even survival often dictate to smallholders to pursue an independent and unique development trajectory. For this reason, although several aspects of sustainability form the basis of their business, they do not meet other sustainability expectations in the absence of wider collaboration and better organization.
\end{abstract}

Keywords: local products, food supply chains, sustainability, rural development.

\section{Introduction}

Food supply is a sector of strategic importance to all. Ensuring the right quality and quantity of food has become easier through technological advances, but as a result of the interplay of broader socioeconomic processes, the role of the agricultural sector has declined significantly even from 1980s [1]. This was also the case in Hungary, between 2000 and 2010 the share of the sector in employment decreased from $6.5 \%$ to $4.6 \%$, and in terms of gross value added from $5.8 \%$ to $3.6 \%$. Thanks to the support programs aimed at the development of the sector and the expansion of rural employment [2], the importance of agriculture did not decrease further in the next decade, and even increased somewhat (employment in 2020: 4.7\%, gross value added in 2019: 4\%). Significantly different statistical indicators on agriculture in European countries also highlight the effectiveness of different support policies and the fact that economic performance cannot be the sole consideration. The successful development of today's agricultural sector can only take place with increased socio-economic embeddedness [3]. Keeping in mind the aspects of sustainable development, we need to see what farmers can do for the benefit of the population (consumers) and vice versa.

The European Union rural development policy for 2014-2020 places greater emphasis on short supply chains than before, an opportunity that Hungary has also taken advantage of. The frequency of producer markets in the country is significantly lower than usual in Western Europe, however, the demand for more direct contact and cooperation of market participants is growing more and more on the part of both producers and consumers. Various definitions of short supply chains can be found in the literature [4-6], i.e. the definition of short supply chains is not always clear at both national and European level. SSCs are often used as a collective term [7], in contexts that have related economic, sociocultural, political, or organizational characteristics and have different impacts on the local economy. Regulation (EU) No. 1305/2013 of the European Parliament and of the Council defines the Short Supply Chain as a supply chain made up of a small number of economic operators committed to cooperation, local economic development and close geographical links between producers, processors and consumers and social relations. Short transport distances and more extensive production methods also raise positive sustainability aspects of SSCs, which, however, have been questioned in several studies [8].

In September 2015, the UN General Assembly adopted the new 2030 Sustainable Development Framework, which set out 17 sustainability goals [9]. Each goal has several targets and tasks that specify it. However, in the opinion of Faragó, the fulfillment of the goals and objectives of the new program 
proves to be a difficult task both at the international and national level [10]. The growing interest in SSCs is due to the fact that they can contribute to more sustainable rural development and healthier food $[11,12]$. According to Benedek, SSCs are designed to find a solution to a wide range of sustainability problems, but the positive social, economic and environmental impact can often not be clearly demonstrated with scientific rigor, and its measurement is difficult [13].

The SKIN project, supported by the European Union, is building a new network based on direct contacts, where producers and consumers are connected by food through the Short Supply Chain (SKIN, Horizon, 2020). Its goals include overcoming the "fragmentation" of knowledge; to connect the two endpoints of Short Supply Chains; to bring together all SSC actors; build and strengthen mutual trust; to establish a short chain based on common values, quality and production methods; encouraging bottom-up and demand-driven innovation.

Jarzebowski et.al within the SKIN project analyzes good practice in more than 100 short supply chains in 15 European countries in three dimensions of sustainable development. Good practices can be found in the short supply chain knowledge and innovation site designated Network (SKIN) website (SKIN, Horizon, 2020). Most of the good practices examined were identified in Austria (13 cases), Hungary (13 cases), the United Kingdom (10 cases) and Ireland (10 cases). Based on the case studies of the European countries studied, all aspects of sustainability prevail in the SSCs [14]. However, in terms of good practices in Hungary, in none of the 13 cases did the markets/events/initiative for multiple producers locally prevail within the economic dimension, consumer empowerment and well-being within the social dimension, and food waste among the environmental aspects (Fig. 1).

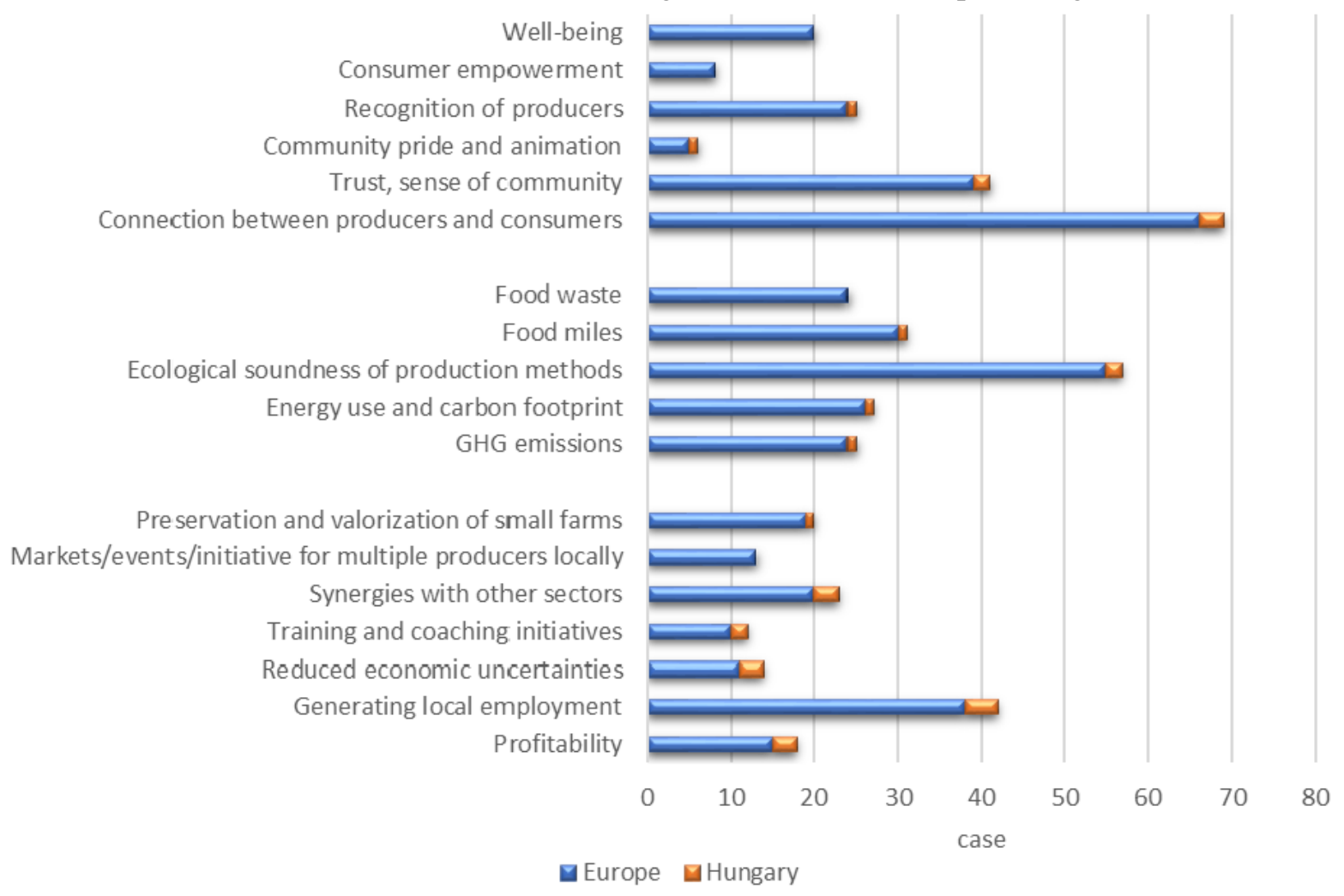

Fig. 1. SFSC good practices within sustainability dimensions, source: [14] and own elaboration based on SKIN project

Jarzebowski et al. (2020) concluded that SFSCs, as local structures, support all three dimensions of the concept of sustainability, which encourages multifunctionality in agriculture and meeting the needs of the consumer and producer side. In general, short chains meet the societal need to provide quality food while reducing the environmental impact of agriculture [14].

According to Zimon et al. the achievement of sustainability goals in supply chains is fundamentally influenced by the internal and external drivers motivating their achievement among the actors in the supply chain, who can also have a significant impact on each other. Sustainable Development Goals fit 
very well with the practices implemented under the sustainable supply chain management, and their integration in the supply chain management process can stimulate synergistic effects. However, their exploitation requires further research and precise guidance for supply chain actors [15]. Applying the circular economy approach, examining the entire life cycle of a product, we can point out which steps violate the aspects of sustainability the most and what change or involvement of actors could solve the problem [16]. Food chain actors can make their activities more conscious and precise with the help of food safety management systems (e.g., ISO 22000), which can have many positive aspects in terms of sustainability [17]. However, these changes are not always the result of conscious construction. Principato et al. pointed out how household consumption habits changed during the Covid-19 lockdown. As food planning and management became more informed, the amount of food waste decreased significantly [18].

As we have seen from the literature, SSCs can have a number of positive effects on sustainability aspects. In addition, researchers and practitioners have developed a number of methods for how sustainability can be measured and how supply chains can perform better. In our study, we did not aim to collect good practices, but to explore what decisions Hungarian local producers have to make in market competition and how compatible their practice with the different dimensions of sustainability.

\section{Materials and methods}

In the course of our study, the sustainability aspects prevailing in the short supply chains were analyzed in the grouping also used by the SKIN project, the concept of sustainability was broken down into 17 points, and then summarized in three pillars (social, economic, and environmental). (Table 1).

Sustainability aspects based on the SKIN project

Table 1

\begin{tabular}{|c|c|c|c|}
\hline \multirow{3}{*}{ Aspects } & \multicolumn{3}{|c|}{ Pillars } \\
\hline & $\begin{array}{c}\text { Economic } \\
\text { Sustainability }\end{array}$ & Social Sustainability & $\begin{array}{l}\text { Environmental } \\
\text { Sustainability }\end{array}$ \\
\hline & $\begin{array}{ll}- & \text { Profitability } \\
\text { - } & \text { Generating local } \\
\text { - } & \text { Reduced economic } \\
& \text { uncertainties } \\
\text { - } & \text { Training and coaching } \\
& \text { initiatives } \\
\text { - } & \text { Synergies with other sectors } \\
\text { - } & \text { Markets/events/initiative for } \\
& \text { multiple producers locally } \\
\text { - } & \text { Preservation and } \\
& \text { valorization of small farms }\end{array}$ & $\begin{array}{ll}\text { - } & \text { Connection between } \\
\text { producers and } \\
\text { consumers } \\
\text { - } & \text { Trust, sense of } \\
\text { community } \\
\text { - } & \text { Community pride and } \\
\text { animation } \\
\text { - Recognition of } \\
\text { producers } \\
\text { - } \text { Consumer } \\
\text { empowerment } \\
\text { - Well-being }\end{array}$ & $\begin{array}{ll}\text { - } & \text { GHG emissions } \\
\text { - } & \text { Energy use and } \\
& \text { carbon footprint } \\
\text { - } & \text { Ecological } \\
& \text { soundness of } \\
& \text { production methods } \\
\text { - } & \text { Food miles } \\
\text { - } & \text { Food waste }\end{array}$ \\
\hline
\end{tabular}

Source: Edited based on SKIN Horizon2020

As we found information mainly on potential positive impacts and good practices on sustainability aspects in short supply chains, we focused our research on local producers who do not necessarily operate in model SSCs, but developed the sales framework themselves. This is also proved by the fact that Hungary's Rural Development Program was able to support only 11 applicants nationwide in the period 2014-2020 within the framework of the tender support entitled "Support for Cooperation for the Establishment, Development and Promotion of SSC and Local Markets". In our primary research we included 20 farmers and agricultural enterprises from the territory of Northern Hungary, who were selected by stratified sampling from our list of local producers, which was compiled by updating, and updating various (local, regional and national) databases available on the Internet. As for the actors included in the study, it can be said that they do not necessarily reflect the entire population, as producers who are also clearly visible to the Internet have been preferred. The activities of the studied actors are typically related to those products (raw and processed vegetables and fruits, honey, homemade dairy and meat products, wine and brandy) which, based on the experience of previous research [19], are of the greatest importance (Fig. 2). 


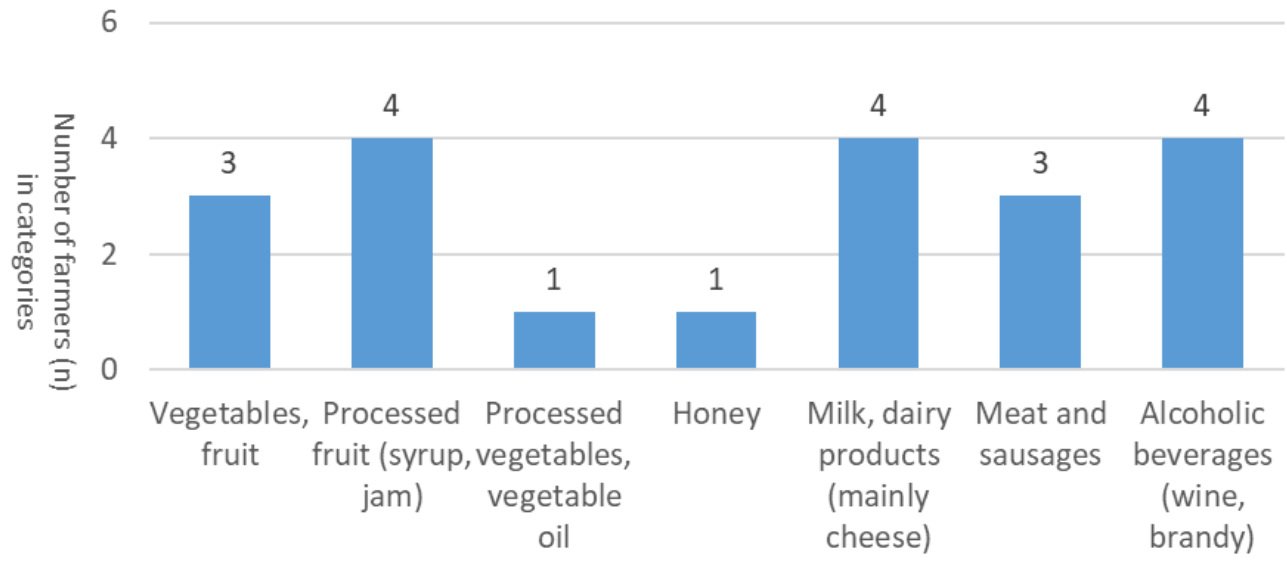

Fig. 2. Primary product categories produced by surveyed farmers, $s$ ource: own editing, 2021

The producers included in the investigation can be divided into two main groups based on the history of their activities. The smaller group ( 8 people) consists of those whose parents and grandparents already worked in the sector, for them a quasi-straight path led to becoming a local producer. At the same time, the more populous group are those who have switched professions to food production, most of whom have their first degree in another field (including former humanities, lawyers, mechanical engineers, etc.). For start-ups, it may be particularly true that they have sought to exploit the natural resources of their region in some innovative way, on the basis of which they have been able to develop their own markets. This work has been recognized in 11 cases (in the form of a trademark, diploma) by experts interested in the development of the region or sector, and the representatives of the press are also accountable for their activities. Each actor is involved in some form of short supply chain (typically not one), but this is not organized, with retail and web stores acting as intermediaries in addition to direct sales. 15 companies have a history of at least five years, three of the new entrants have benefited from start-up aid for young farmers.

Primary data collection took place in January and February 2021. We interviewed the producers involved in the study, the questions in the interview outline covered aspects of sustainability. The 20 interviews were mostly conducted in person and partly by telephone. In this way, we obtained mainly qualitative information, but in several cases local producers were also able to provide quantitative data. In addition to the personal interview, we also collected additional information available on the Internet about the producers.

\section{Results and discussion}

The first of the sustainability aspects is the economy, whose role is essential for the continuation of production in the short term. It is important that the production and sale of local products be profitable, for which, however, the benchmark is important. The vast majority of producers believe that revenues are often disproportionate to the work done and the degree of risk-taking. We also find an example of the fact that in some years the activities can only be described as profitable together with the EU grants. If we compare these enterprises with the same indicators of industrial enterprises, we can report that agricultural enterprises lag behind them both in terms of size and profitability. However, on the other hand, this sector is supported by the love of the profession on the part of producers, the fact that they can go their own way and that their work is better known and recognized by the local community.

The companies surveyed either do not play a significant role in local employment at all or temporarily generate higher labor demand during seasonal work. The number of permanent employees is a maximum of 5, but it should be noted that it is characteristic of several family farms that they are divided into several companies due to more favorable tax conditions. The sale of specialty products with higher added value often requires this. In many cases, it is random where producers find the right partner geographically and where to organize sales. Well-known producers may be invited to several outlets on weekends, but it is not possible for them to be present in more than two markets and/or fairs in parallel. The decision is made based on their own past experience. As the organization of short supply chains is not the responsibility of external actors, the reduction of economic uncertainties is a matter of self- 
determination. As a result, they make little use of the management opportunities mentioned in the relevant literature [13-17].

As the point of sale is often not within the narrower area, there is little local recirculation of community income. This is due to the fact that farmers can fill smaller market niches with more specialized local products. Significant demand for products is manifested only in larger cities (mainly in the capital), it is not profitable to export these products to smaller markets, because often even wages and rents do not recoup from scarce revenues. Local sales, typically in the markets of district centers, come to the fore in producers for which there is a higher demand (eg vegetables, fruit, honey, cheese). The role of intra-district sales is also dominant when sales are made in-house, in conjunction with tourism service providers, or at local events. Together, they make up $40 \%$ of the sample. Sales outside the district, but even within the county (e.g., in the markets of the county seat or other cities) are less popular. In the first place, through the capital and some cities outside the county, the more distant markets with higher demand came into play (Fig. 3).

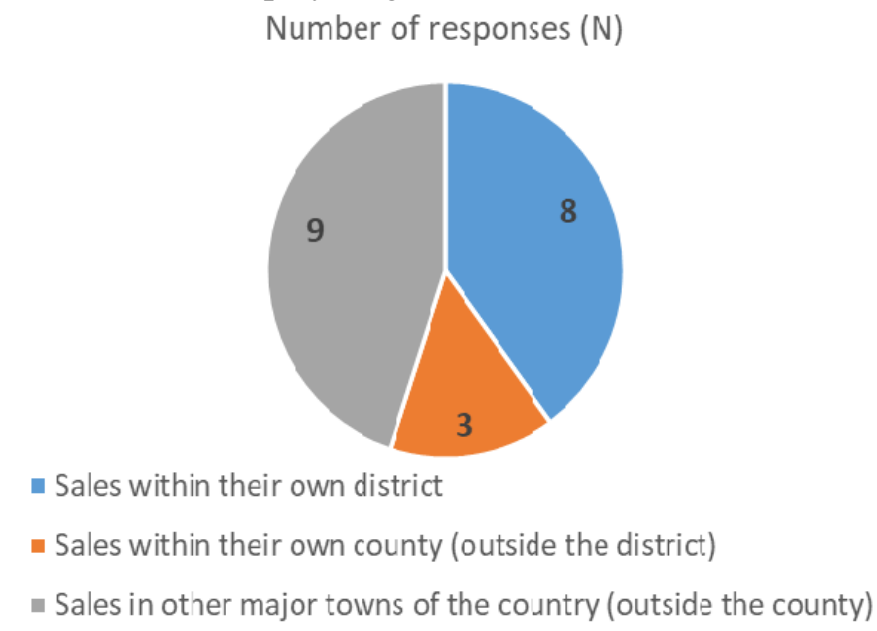

Fig. 3. Geographical distribution of the primary place of sale, source: own editing, 2021

The number of interconnection points between sectors is minimal. This is due to the fact that the majority of local producers specialize in high-quality and at the same time more expensive products, which the local market does not provide, so they have to cooperate with actors outside the region. Among the quality parameters of food, not only uniqueness is manifested, but also the consistently high standard. Due to the fact that the products can be directly associated with the person of the producers, on the other hand, the producers are characterized by a strong commitment to the professional, they themselves are constantly working to improve their activities. Thus, they also contribute to the achievement of wider community (even EU) objectives through their own professional motivation, as an internal driving force [15].

Among the positive social impacts of short supply chains, the development of more direct links between producers and consumers can play an important role. This is possible for each of the producers examined, but to a different extent - there are places where this is largely done through employees, who are often as committed as the farmers themselves. However, it has also been pointed out by several that $10-20 \%$ more products are consumed when the farmer is personally involved in the sale. Eight of the farmers sell their products at markets and fairs. In addition, there are three people who have integrated sales into rural hospitality and tourism programs, one producer is involved in the "take it yourself" movement and one is solving sales at home. For the other players, sales are mainly made via the Internet or to catering establishments. Especially in connection with wine tastings, it can be said that consumers can get acquainted with the process of producing the product. There are only three "more open" economies where those interested can get an insight into manufacturing technology and even try it out.

The formation of the regular customer base increases the trust within the value chain, living collaborations are also established between the actors producing different products, even by associating the products (e.g.. compiling a gift package). We mentioned earlier that several local producers are also very popular in the media, as the results they achieve are recorded as a success in rural development by 
the local community. However, participation in local events is typical only of a narrower group of producers (e.g., winemakers, cheesemakers), several stated that in their previous experience they were not financially worthy of participation (a more profitable sales opportunity was canceled due to it). On several occasions, producers from a further field $(50-150 \mathrm{~km})$ at local events make more use of the opportunity to sell. Some local producers do not have such a strong relationship with the local community from the outset, as the focus of their sales is on intermediaries or residents of large cities. At the same time, several producers experienced exposure to operators in metropolitan markets due to high rents and the fact that they also allowed resellers into the market who could not compete with their prices. Based on different measurements of social performance [15], the success of producers is very unequable.

The environmental aspects of sustainability appear in the communication of practically all the examined companies, following the traditional forms of production they try to manage the available natural resources well. However, the size, scope and capital strength of farms allow the use of different technologies. The use of modern equipment with higher capacity can also have a positive effect on the environmental load emission parameters per unit of the production process. In this context, we have to distinguish between those farms (7) that have developed further from backyard activities over time and those that can rely on a more significant past and knowledge base.

Some of the surveyed local producers are characterized by lively tendering activity. In the spirit of environmental sustainability, it should be mentioned that two medium-sized farmers in the sample sought to improve their position by switching to organic farming, trusting in the higher prices available for organic food and their positive consumer perception. Three viticulture and one fruit growers have benefited from the agri-environmental management program, which requires the preservation and improvement of environmental conditions, the reduction of environmental pressures and the dissemination of sustainable agricultural practices. It is important to emphasize that the formulation of environmental objectives is not only important for the companies participating in the tender programs, they are aware that this is in their basic interest (e.g., the installation of bee colonies, bird birds, the creation of grassland).

With regard to the utilization of natural resources, companies producing syrups, jams and brandies mobilize naturally available raw materials (wild berries, flowers and herbs) that would otherwise be inferior. Added to this is the fact that no agricultural land is used to produce these products.

Determining the amount of losses and waste is an important issue in a food supply chain. In developed countries, about a third of this occurs in consumers and two-thirds in production and trade [20]. With the reduction in the number of actors in short supply chains, there is a greater burden in this respect on producers, who, of course, have a financial interest in minimizing the proportion of goods they are unable to sell. Companies that are in continuous product development by developing new recipes are more likely to do so. However, most local products can be processed in a form (in a volume that meets market needs) that can be stored for a longer period of time and can also add value. For raw materials that can be utilized in several phases, a strategic decision may be to share them (e,g., syrup made from elderflower flowers and fruits). Environmental awareness in these economies is not based on modern technologies and well-designed procedures [16,17], but on core values and the rapid, effective management of emerging problems.

In connection with the discussion of environmentally friendly technologies, the literature attaches great importance to the issue of packaging [21]. For farmers who sell on the market, door-to-door, homedelivery, or catering, the amount of packaging used can be minimal. It can also be advantageous to sell in a larger package than usual at retail (e.g., juices in a 3-5 liter box instead of 1 liter). At the same time, the other half of the local producers make a special effort to draw attention to the uniqueness of their product with a distinctive image. Thus, although a significant part of the packaging material is recyclable, it is more likely to be made in households than repeatedly by the producer (with the exception of wine bottles in our case).

With regard to the environmental impacts of supply chains, we have recently left out the importance of transport, which is perhaps the most frequent and examined by several indicators, the distance of which can differ significantly between long and short chains. The length of transport affects both energy use and greenhouse gas emissions [22]. Due to the transport distance and quantity of the examined local 
products, only road transport can play a role in the transport, especially the producers' own, van and station wagon-sized vehicles. It may be beneficial for producers to be able to sell locally (11 producers), but in this case the environmental burden will be on the side of consumers. In the short supply chain, sales typically take place within $40 \mathrm{~km}$ of the producer's headquarters, but the legal exception is Budapest, the capital and its agglomeration, where, in addition to higher and more diversified demand, the relative number of local producers is lower. Thus, there is a producer who, although $75 \mathrm{~km}$ from the capital, organized its sales with a center there. Producers who do not have a sufficient consumer demand within their own district should give preference to metropolitan (capital, county seat) outlets located 50$100 \mathrm{~km}$ away instead of the market 5-10 km away. However, this is still not a significant distance, but the specific indicators are worsened by the small quantity transported, on the other hand, by the fact that several farmers have obsolete (10-20 years old) vehicles with worse emission parameters. In addition, special needs are manifested not only in the market, but also in the technology of product production. One producer interested in animal husbandry and the production of meat products mentioned that he had to transport the animals to a slaughterhouse $80 \mathrm{~km}$ away and, due to the application of a special recipe, the meat raw material transported $210 \mathrm{~km}$ for processing.

We examined two specific cases the extent to which transporting local products over longer distances could lead to $\mathrm{CO}_{2}$ emissions. We intentionally processed the data of two operators who transport different types of goods over similar distances, from which they can sell very different quantities on a market day. Our calculation showed that individually organized sales (not coordinated with other producers) can result in extremely high specific emissions data due to the small amount of goods. (Table 2).

Table 2

Transport-related carbon footprint data based on two specific examples

\begin{tabular}{|c|c|c|c|c|c|c|c|c|c|}
\hline $\begin{array}{l}\text { Product } \\
\text { name }\end{array}$ & $\begin{array}{l}\text { Quantity } \\
\text { sold (kg) }\end{array}$ & $\begin{array}{c}\text { Sales } \\
\text { price } \\
\text { kg-1 }^{-1} \\
\left(\text { HUF* }^{*}\right)\end{array}$ & $\begin{array}{c}\text { Total } \\
\text { sales } \\
\text { revenue } \\
\text { (HUF) }\end{array}$ & $\begin{array}{c}\text { Total } \\
\text { distance } \\
\text { traveled } \\
(\mathbf{k m})\end{array}$ & 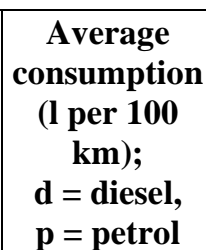 & $\begin{array}{c}\mathrm{CO}_{2} \\
\text { emissions } \\
\text { (g) per } \\
\text { liter of } \\
\text { fuel }\end{array}$ & $\begin{array}{c}\text { Total } \\
\mathrm{CO}_{2} \\
\text { emissions } \\
\text { (g) }\end{array}$ & $\begin{array}{c}\mathrm{CO}_{2} \\
\text { emissions } \\
\text { (g) per } \\
\text { kg of } \\
\text { goods }\end{array}$ & $\begin{array}{c}\mathrm{CO}_{2} \\
\text { emissions } \\
\text { (g) for } \\
\text { sales of } \\
\text { HUF } \\
1,000\end{array}$ \\
\hline Sausage & 12 & 7000 & 84,000 & 152 & 7.5 & 2,392 & $27,268.8$ & $2,272.4$ & 324.6 \\
\hline $\begin{array}{l}\text { Table } \\
\text { grape }\end{array}$ & 600 & 400 & 240,000 & 156 & 11.0 & 2,640 & $45,302.4$ & 75.5 & 188.8 \\
\hline
\end{tabular}

* $1000 \mathrm{HUF}=2.807 €(360$-day average price on March 19, 2021)

Source: Own editing based on information provided by producers, 2021.

\section{Conclusions}

Our study has shown the extent to which the economic, social and environmental aspects of sustainability prevail (or not) in individually organized short supply chains that differ from model-like operation. Due to the small size of farms and the lack of co-operation, it is often not possible to introduce the procedures mentioned in the literature that could make the sector more sustainable. The basis of the whole range of activities is determined by the economic aspects, in connection with which the most important expectations are met (presence of permanently well-functioning family farms), but several potential positive effects are lacking due to weak producers' relationship with the local market and community. The activities of producers and their role in rural development are known to a relatively large number of people, but not always due to personal contact, but often due to the media presence. The development of the system of relations within the region is realized primarily among the regular customers of the producers. Environmental impacts outweigh economic and social impacts in several ways, which is due to the fact that these objectives are often reflected in farmers' business policies, as consumers expect a healthier and more environmentally friendly product for a higher purchase price. However, due to the fragmentation of the delivery of the products sold, the specific output indicators of sales can be extremely unfavorable, which calls for increased attention to expand cooperation and more rational organization of local food systems. With our study, we pointed out how diverse the aspects of sustainability are in the practice of short supply chains in Hungary. The tools mentioned in the relevant 
literature, which could improve sustainability indicators, are rarely used. Practical experience sometimes gives rise to innovative and forward-looking solutions. However, in the future, these farmers will need to implement more precise regulation of the processes.

\section{References}

[1] Anderson K. On Why Agriculture Declines with Economic Growth. Agricultural Economics 1, 1987, pp. 195-207.

[2] Tóth O. Atypical forms of employment in Hungarian agriculture. Annals of the Polish Association of Agricultural and Agribusiness Economists 15(5), 2013, pp. 324-329.

[3] Feenstra G. Local Food Systems and Sustainable Communities. American Journal of Alternative Agriculture 12(1), 1997, pp. 28-36.

[4] Ilbery B., Maye D. Alternative (shorter) food supply chains and specialist livestock products in the Scottish-English borders, Environment and Planning A, 37, 2005, pp. 823-844.

[5] Peters R. (Ed.) Local Food and Short Supply Chains, EU Rural Review N ${ }^{\circ} 12,2012,67$ p.

[6] Parker G. Sustainable Food? Teikei, co-operatives and food citizenship in Japan and in the UK. Working Paper in Real Estate and, Planning. 2005, 11/05, 29 p.

[7] Marsden K., Banks J., Bristow G. Food supply chain approaches: exploring their role in rural development. Sociologia Ruralis 40, 2000, pp. 424-438.

[8] Kiss K., Ruszkai Cs., Takács-György K. Examination of Short Supply Chains Based on Circular Economy and Sustainability Aspects. Resources 8(4), 2019, Paper 161.

[9] The Sustainable Development Framework 2030 - Agenda 2030.

[10] Faragó T. Our world in 2030: antecedents, essence and evaluation of the new universal program of international cooperation. (In Hungarian) Külügyi Szemle 15(2), 2016, pp. 3-24.

[11] Corrigan M. P. Growing what you eat: developing community gardens in Baltimore, Maryland. Applied Geography 31(4), 2011, pp. 1232-1241.

[12] Wakefield S., Yeudall F., Taron C., Reynolds J., Skinner A. Growing urban health: community gardening in South-East Toronto. Health Promotion International, 22(2), 2007, pp. 92-101.

[13] Benedek Zs. Impacts of short supply chains. Summary based on international and domestic experience. (In Hungarian) Magyar Tudományos Akadémia Közgazdaság és Regionális Tudományi Kutatóközpont, Mühelytanulmányok, 2014, 48.p.

[14] Jarzebowski S., Bourlakis M., Bezat-Jarzebowska A. Short Food Supply Chains (SFSC) as Local and Sustainable Systems. Sustainability 2020, 12, 4715.

[15]Zimon D., Tyan J., Sroufe R. Drivers of sustainable supply chain management: Practices to alignementwith un sustainable development goals. International Journal for Quality Research 14(1), 2020, pp. 219-236.

[16] Principato L., Ruini L., Guidi M., Secondi L. Adopting the circular economy approach on food loss andwaste: The case of Italian pasta production. Resources, Conservation and Recycling 144, 2019, pp. 82-89.

[17]Zimon D., Madzik P., Domingues P. Development of Key Processes along the Supply Chain by Implementing the ISO 22000 Standard. Sustainability 2020, 12, 6176.

[18] Principato, L., Secondi, L., Cicatiello, C., Mattia, G. Caring more about food: The unexpected positive effect of the Covid-19 lockdown on household food management and waste. SocioEconomic Planning Sciences, 2020, 100953.

[19] Kiss K., Ruszkai Cs., Szücs A., Koncz G. Examining the Role of Local Products in Rural Development in the Light of Consumer Preferences - Results of a Consumer Survey from Hungary. Sustainability 12(13), 2020, Paper 5473.

[20] Agoda S., Ihionu G. C., Atanda S. A., Osegbo A. Post-Harvest Loss Reduction as a Tool for Food Security. Acta Velit 3(1), 2016, pp. 56-67.

[21] Pauer E., Wohner B., Heinrich V., Tacker M. Assessing the Environmental Sustainability of Food Packaging: An Extended Life Cycle Assessment including Packaging-Related Food Losses and Waste and Circularity Assessment. Sustainability 2019, 11, 925.

[22] Wakeland W., Cholette S., Venkat K. Food transportation issues and reducing carbon footprint. J.I. Boye and Y. Arcand (eds.), Green Technologies in Food Production and Processing, Food Engineering Series, 2012, pp. 211-236. 